\title{
THE DEVELOPMENT COMMUNITY CAPACITY FOR WOMEN ENTREPRENEURSHIP WITH BUSINESS BLOG TRAINING
}

\author{
Safitri Juanita $^{1 *}$, Reva Ragam Santika ${ }^{1}$, M Anif $^{1}$, Dolly Virgian Shaka Yudha Sakti ${ }^{1}$ \\ ${ }^{1}$ Faculty of Information Technology, Budi Luhur University \\ *Safitri.juanita@budiluhur.ac.id
}

\begin{abstract}
Based on projected population growth, Ministry of National Development PlanningRepublic of Indonesia, The Indonesian Central Bureau of Statistics and United Nations Population Fund, Indonesia's population reached 265 million in 2018 out of which 131.88 million population is female gender. According to the Head of Indonesian Creative Economy Agency Triawan Munaf, more than $30 \%$ of creative economy entrepreneurs in Indonesia are millennial generation and $55 \%$ of creative economy entrepreneurs are woman. According to the Minister of manpower and transmigration Republic of Indonesia Hanif Dhakiri revealed that women entrepreneurs in Indonesia increased from 14.3 million to 16.3 million in 2017. Beside that the growth of E-Commerce sector is quite good in 2017, making this sector still a prima donna. investors in 2018. The Investment Coordinating Board Of The Republic Of Indonesia (BKPM) revealed that the investment value in the E-Commerce sector in 2017 reached more than USD 5 billion.This makes E-Commerce the most strategic economic sector today. Seeing these opportunities, it is necessary to build community capacity for women entrepreneurs, especially taking advantage of opportunities brought by " Information Technology " Businesses use IT to share information by utilizing blogs as free online stores through training in creating business blogs. The method that we used for computer training are giving theory with learning module and practicum modules, then participants will follow the instructions by creating their own blog and trainer will give task to participants and we will give training evaluation by giving a questionnaire to get feedback from the participants. The conclusion of this research paper is based on the activities that aredevelopment community capacity for woman enterprenuership with business blog training has proceeded according to plan,it can be seen from the results of the evaluation that most participants understand the material of training and can practice on easilyand get the benefits from the training conducted.
\end{abstract}

Keywords: Blog Training Community, Computer Training, Woman Enterpreneurship

\section{INTRODUCTION}

Based on projected population growth, Ministry of National Development PlanningRepublic of Indonesia, The Indonesian Central Bureau of Statistics and United Nations Population Fund, Indonesia's population reached 265 million in 2018 out of which 131.88 million population is female gender (BPS, 2013). According to the Head of Indonesian Creative Economy Agency Triawan Munaf, more than $30 \%$ of creative economy entrepreneurs in Indonesia are millennial generation and $55 \%$ of creative economy entrepreneurs are woman (CNBCIndonesia, 2018). According to the Minister of manpower and transmigration Republic of Indonesia Hanif Dhakiri revealed that women entrepreneurs in Indonesia increased from 14.3 million to 16.3 million in 2017 (Metrotvnews, 2017). Beside that the growth of E-Commerce sector is quite good in 2017, making this sector still a prima donna. investors in 2018. The Investment Coordinating Board Of The Republic Of Indonesia (BKPM) revealed that the investment value in the E-Commerce sector in 2017 reached more than USD 5 billion. This makes ECommerce the most strategic economic sector today (Iskandar, 2018).Seeing these opportunities, it is necessary to develop community capacity for women entrepreneurs, especially taking advantage of 
opportunities brought by " Information Technology " Businesses use IT to share information by utilizing blogs as free online stores through training in creating business blogs.

To realize the development of Community Capacity for Women Entrepreneurship With Business Blog Training we cooperate with community organizations named SALIMAH to plan activities to increase the capacity of woman enterpreneurs through free business blog training. The SALIMAH organization is a community organizations in the Republic of Indonesian whose members are all women, until now this organization is in 33 provinces, 346 cities and regencies, 1,183 districts and 285 villages or villages throughout Indonesia. One of the branch is located in Tangerang City and one of SALIMAH organizational work programs is improvement of education for women and make business in the economic field, so some of member in Salimah were Women Entrepreneur.

The purpose of this community service activity is to provide knowledge for woman about how to using computer applications, especially utilizing the use of internet technology as an E-Commerce tool that can be increase sales revenue for woman enterpreneur.The benefits of this training activity for the community are to improve the skills or knowledge for women how to using information technology, especially to build women's entrepreneurial capacity by utilizing blogs as business blogs, contribute to the Republic of Indonesia government in socializing the use of internet technology and improving the quality of Indonesian human resources, especially in the field of computers.

\section{METHOD}

\section{Design Activity Planning}

The following figure 1 is design activity planning for community services:

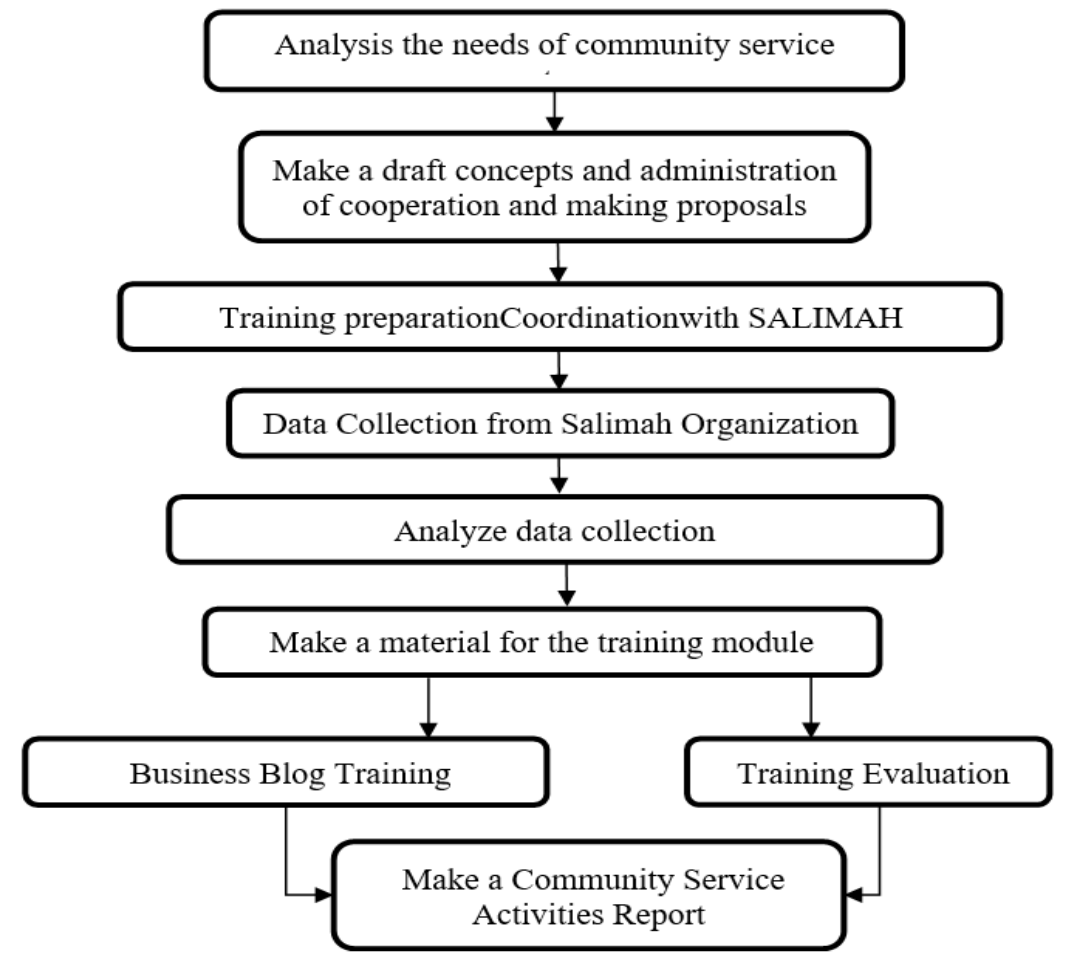

Figure 1. Design Activity Planning

The method used in community service is as follows:

- Interview

We interviewed Mrs Nurjanah, S.Pd.I as chairman of the Salimah branch of Tangerang city to find out the required needed by training participants, how to attract members of the Salimah organization to participate in training and Coordination Training preparation.

- Training Method 
This training activity is designed with the aim that participants can understand the material presented comprehensively, so that it can be applied applicatively by participants. The method of training activities is carried out based on the process of learning theory and practical learning. The comparison between theoretical learning and practical learning ranges from a ratio of about 1:2. The method of training to convey theory includes: presentation of training material to trainees, answering participant questions and discussions with participants, while the practicum method consists of providing practicum exercises, giving participants the opportunity to give questions and answer participants' questions and give assignments to the trainees. Participants will be given training materials in the format of practicum modules with the distribution of material in the form of files and hardcopy so that it is easier for participants to practice at the time of training or be taken home by participants as material for learning in the future

- Evaluation Design

The evaluation design was carried out by giving the questionnaire to the trainees to receive feedback from the participants' training after they were finished, so we could make improvements for the next training.

\section{RESULTAND DISCUSSION}

\section{Discussion}

The following is a collection of computer training activities

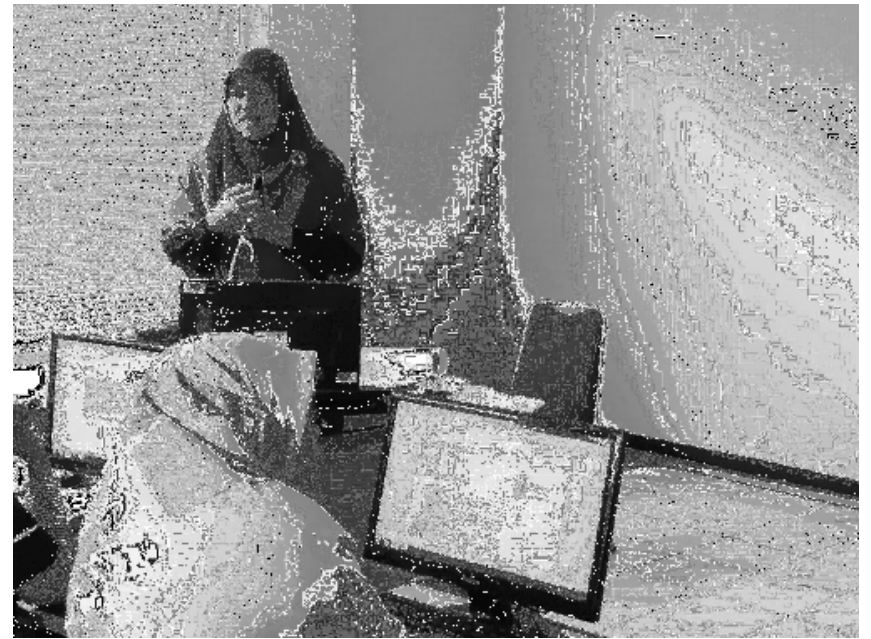

Figure 2. The trainer explains to the training participants about how to making a blog 


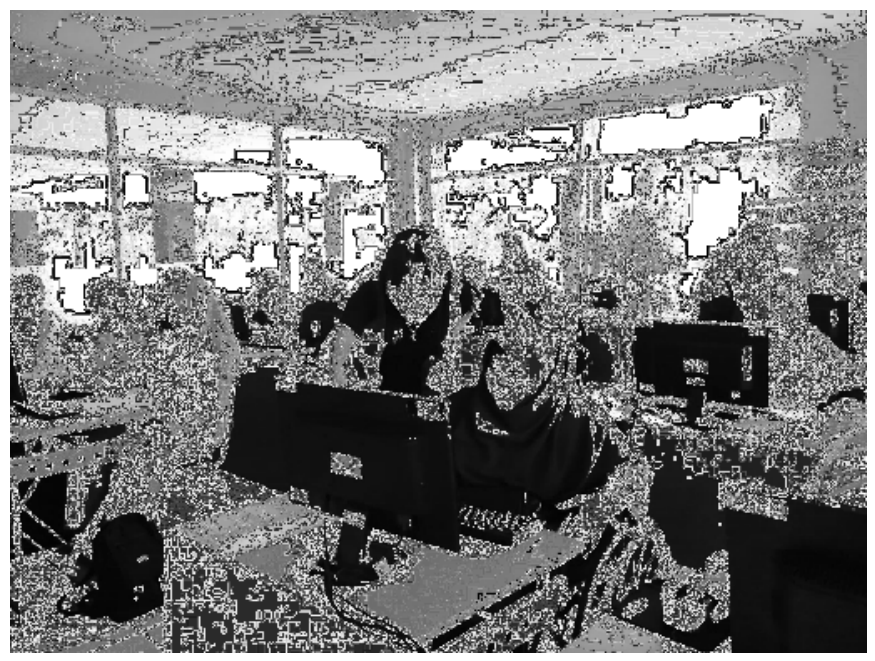

Figure 3. Trainers and assistant trainers help trainees understand the training material

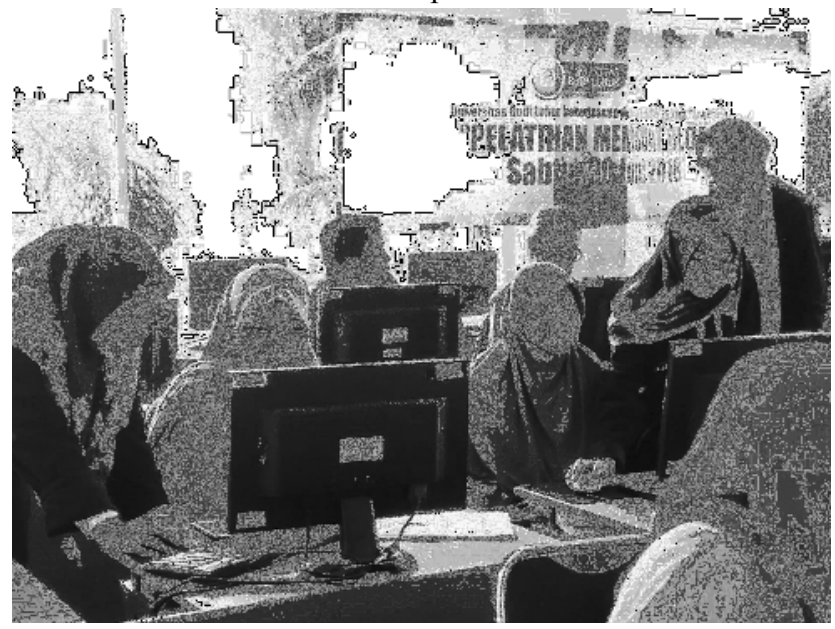

Figure 4. Students as assistant trainers help trainees understand training materials

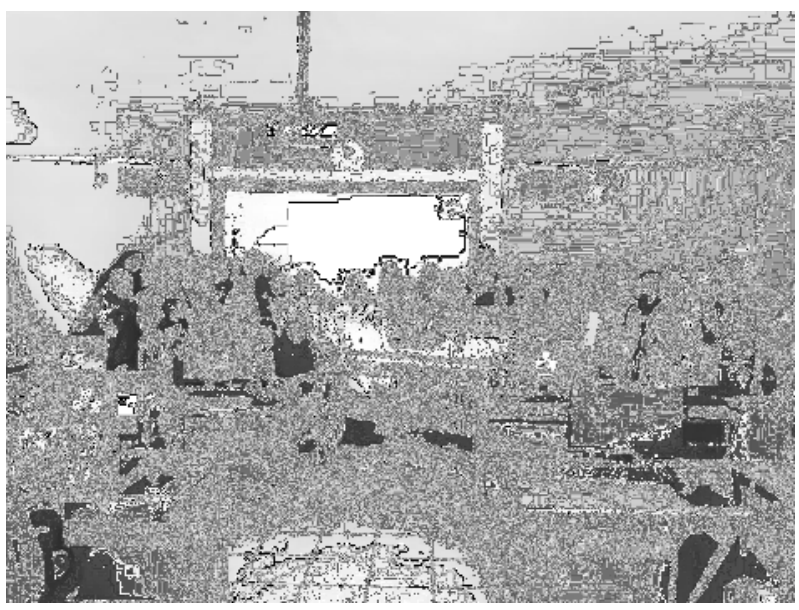

Figure 5. Take a picture together with participants after training was completed 


\section{RESULT AND DISCUSSION}

In this training we provide questionnaires to trainees to evaluate computer training activities, the results of the evaluation can be used as an improvement for further activities. The questionnaire that we used is closed questionnaire so the answer for questionnaire has been provided, the respondent only chooses the answers that have been provided. The questionnaire provides 5 alternative answers, namely "Strongly Agree, Agree, Disagree, Disagree and Strongly Disagree" with all positive questions.questionnaires were distributed to 24 participants.

The following are evaluation results based on participant questionnaires

Questionnaire 1: Computer training material how to create a Business Blog is clear and easy to understand. Based on the results of the questionnaire distributed to participants to find out the contents of the training material whether clear and easy to understand, there were 11 participants who strongly agreed and 13 people agreed with this statement.

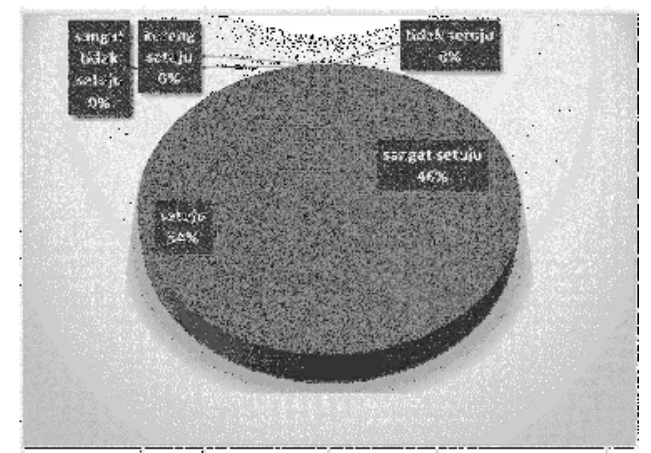

Figure 6. Questionnaire results about training material

Questionnaire 2:Instructor gives opportunities to participants to ask questions

Based on the results of the questionnaire distributed to participants, the number of participants who stated strongly agreed with this statement were 15 participants and 9 participants agreed with this statement.

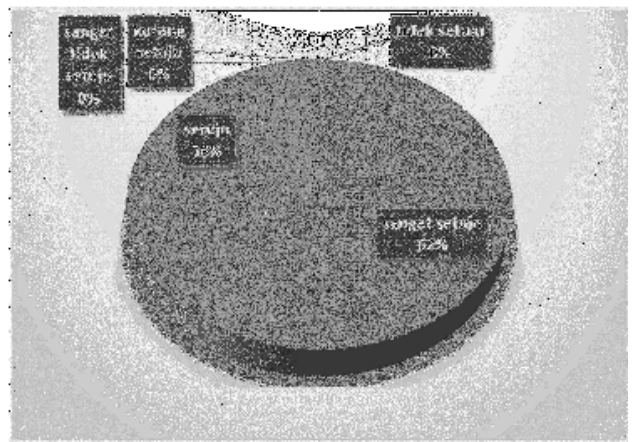

Figure 7. Questionnaire results about instructor gives the opportunity to participants to askquestions

Questionnaire 3: The instructor answers the question clearly and is easy to understand Based on the results of the questionnaire distributed to participants, the number of participants who stated strongly agreed with this statement were 10 participants and 14 participants agreed with this statement. 


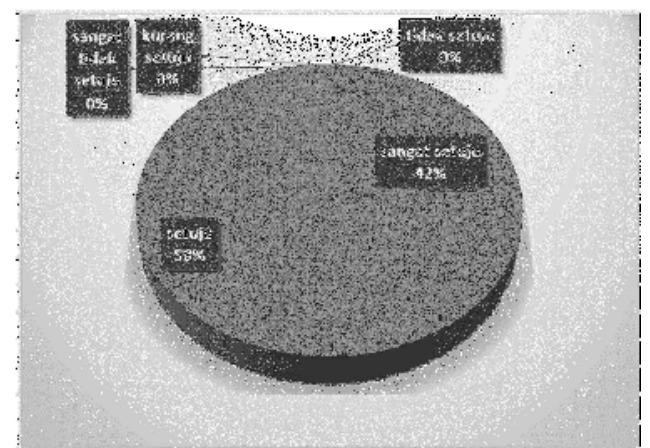

Figure 8. Questionnaire results about instructor answers the question clearly and is easy to understand

Questionnaire 4:The instructor provides examples of practicum exercises clearly and easilyunderstood.Based on the results of the questionnaire distributed to participants, the number of participants who strongly agreed with this statement was 5 participants and 18 participants agreed and 1 participant stated that they did not agree with this statement.

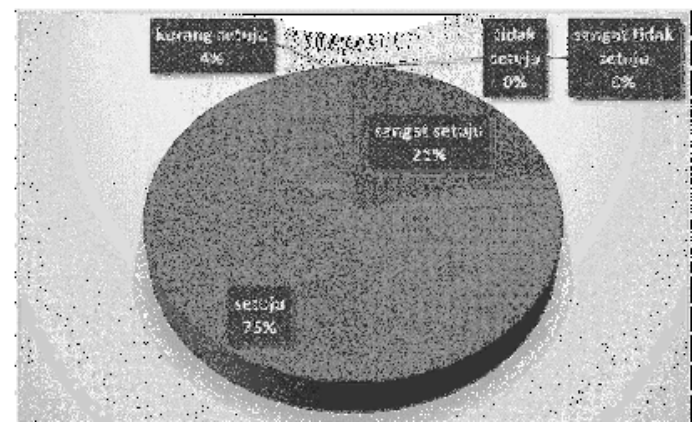

Figure 9. Questionnaire results about instructor provides examples of practicum exercises clearly and easily understood

Questionnaire 5: The instructor and assistant instructor help the trainees so that participants understand the material well. Based on the results of the questionnaire distributed to participants, the number of participants who stated strongly agreed with this statement were 11 participants and 13 participantsagreed with this statement.

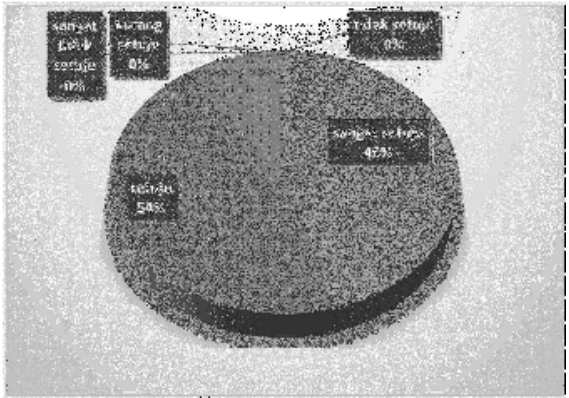

Figure 10. Questionnaire results about instructor and assistant instructor help the trainees so that participants understand the material well

Questionnaire 6: Computer Laboratory Facilities in accordance with computer training needs.

Based on the results of the questionnaire distributed to participants, the number of participants who stated strongly agreed with this statement as many as 10 participants and 13 participants agreed and 1 participant stated that they did not agree with this statement. 


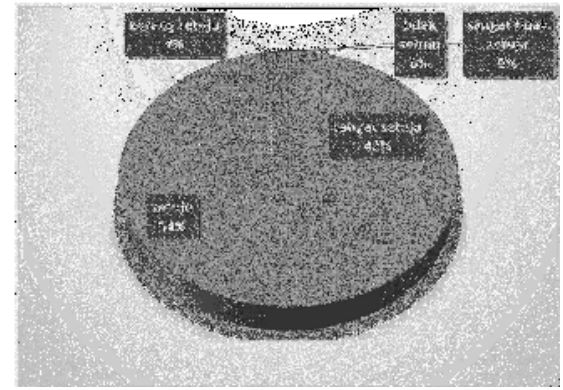

Figure 11. Questionnaire results about Computer Laboratory Facilities in accordance with computer training needs

Questionnaire 7:Computer training activities are useful to increase participants' skills.

Based on the results of the questionnaire distributed to participants, the number of participants who stated strongly agreed with this statement as many as 16 participants and 8 participants agreed with this statement.

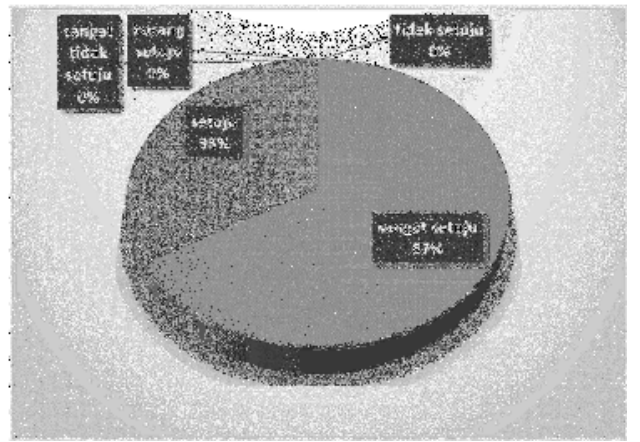

Figure 12. Questionnaire results about Computer training activities are useful to increase participants' skills

\section{CONCLUSION}

From the results and discussion above, the conclusions of the community service activities are as follows:

- Computer training activities had proceeded according to plan.

- The participants were very pleased with the training when they made business blogs as evidenced by the results of the questionnaires which had given to the training participants, most of whom strongly agreed and liked with the material explanation, and they had opportunity to ask questions given to the participants, training facilities, training materials and the services provided were very good.

- Based on the results of the questionnaire, trainees receive the benefits of computer training.

\section{REFERENCES}

BPS. (2013). Proyeksi Penduduk Indonesia 2010-2035. Retrieved from : https://www.bps.go.id/publication/2013/10/07/053d25bed2e4d62aab3346ec/proyeksi-pendudukindonesia-2010-2035.html.

CNBC Indonesia. (2018). 55\% Pelaku Usaha Kreatif di Indonesia adalah Wanita. Retrieved from: https://www.cnbcindonesia.com/entrepreneur/20180316161131-25-7533/55-pelaku-usahakreatif-di-indonesia-adalah-wanita. 
Metrotvnews. (2017). Jumlah Perempuan Wirausaha Capai 16,3 Juta di 2017. Retrieved from : http://ekonomi.metrotvnews.com/mikro/VNxQ3mqb-jumlah-perempuan-wirausaha-capai-16-3juta-di-2017.

Iskandar, Eddy Dwinanto. (2018). Prediksi Tren E-Commerce Indonesia 2018.Retrieved from :https://swa.co.id/swa/listed-articles/prediksi-tren-e-commerce-indonesia-2018. 